\title{
Accounting
}

\section{An economic management system for sustainable development in black sea region}

\author{
Iryna Kramarenko ${ }^{a}$, Inna Irtyshcheva ${ }^{b}$, Svitlana Shults ${ }^{c}$, Marianna Stehnei ${ }^{d}$, Blishchuk Kateryna ${ }^{\mathrm{e}}$, \\ Yevheniia Boiko ${ }^{b}$, Nazariy Popadynets ${ }^{c^{*}}$, Nataliya Samotiy ${ }^{\mathrm{f}}$, Lida Rogatina ${ }^{\mathrm{g}}$ and Nataliya \\ Hryshynab
}

\author{
${ }^{a}$ Mykolaiv Interregional Institute of Human Development of the University "Ukraine”, Ukraine \\ ${ }^{b}$ National University of Shipbuilding named after Admiral Makarov, Ukraine \\ 'SI "Institute of Regional Research named after M. I. Dolishniy of the NAS of Ukraine”, Ukraine \\ ${ }^{d}$ Mukachevo State University, Ukraine \\ ${ }^{e}$ Lviv Regional Institute for Public Administration of the National Academy for Public Administration under the President of Ukraine, \\ Ukraine

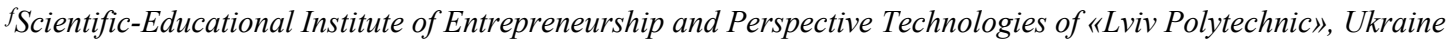
gOdesa National Academy of Food Technologies

\section{H R O N I C L E \\ A B S T R A C T}

Article history:

Received March 72020

Received in revised format March

102020

Accepted May 82020

Available online

May 82020

Keywords:

Black Sea region of Ukraine

Economic system

Social-economic efficiency

Sustainable development

\begin{abstract}
The paper aims to develop a model for measuring economic system management efficiency of the Black Sea region of Ukraine through the context of sustainable development. The model includes the rates of social and economic efficiency, productivity, and performance. The proposed approach calculates the region's economic system management efficiency. The respective evaluation criteria are systematized: economic and social efficiency of the region's economic activity, productivity of the use of resources, and performance of the management system. The system of evaluation indicators by each criterion and mathematical apparatus to calculate them are suggested. The paper suggests methodical approaches to evaluate the economic system management efficiency in the region under transformation. They help determine the current level against similar indicators achieved within the country and the tendencies influenced by regional factors, form the "economic system management profile", and identify the strengths and bottlenecks.
\end{abstract}

\section{Introduction}

The state and regional policy in the era of intensified transformation processes peculiar to the modern stage of Ukraine development should be directed in the first place at the improvement of living standards and achievement of sustainable development of the regional economic system. However, insufficient efficiency of the systems of interregional income and resources distribution, lack of stable structural-innovative advances in the regional economy, insufficient efficiency of financial and investment mechanisms of crisis overcoming, and unbalanced production capacity create obstacles for restructuration and modernization of economic complex in conditions of urgent need to transfer to new technological modes and secure the efficient use of the regions' resources capacity. This causes the need to develop complex strategic solutions regarding the improvement of mechanisms of economic system management in the region that should be based on a detailed analysis of the current condition

* Corresponding author. Tel.: +380969459098

E-mail address: popadynets.n@gmail.com (N. Popadynets) 
and existing trends of economic capacity development. The development of complex strategic solutions regarding the improvement of mechanisms of economic system management in the region should be based on the results of continuous monitoring of main socio-economic development indicators in the region. Therefore, the construction of the model of economic system management efficiency for the Black Sea region of Ukraine in the context of investment capacity development is quite relevant.

\section{Literature review}

There have been many scientific studies devoted on the construction of the models to evaluate the efficiency of a country's investment capacity and socio-economic development. The systems of management of a company's economic development are also separately examined. The developed model of evaluation of a country's capacity to attract investment includes the development of a five-factor non-linear regression of the dependence of a Global Foreign Direct Investment Country Attractiveness Index on five integrated indices of the groups with Cobb-Douglas function and evaluation of a country's capacity to attract investment by adaptation of Hurst exponent (Kasaeva, 2019). The application of such an approach provides an opportunity to define major priority directions of public regulation and support of integration systems development in agri-food (Stroyko et al., 2013, 2015). Creation of formalized model of the companies' economic development included the levels of organization-technological and informational-managerial development (Skvortsov \& Heorhiadi, 2012; Khaustova et al., 2017, 2019; Yakubiv, 2015; Yakubiv et al., 2020). Proper attention should be paid to the model of antagonistic behavior of socioeconomic systems' entities. The bipolar model of the arms race for two parties (countries) can be represented by the system of differential equations (Richardson, 1960). Mathematical model of social systems based on the description of behavior by macro variables (consumption rates, investment, political and religious views) is separately substantiated (Weidlich, 1988; Kolomiyets et al., 2016, Barna et al., 2017; Pahuhnyk et al., 2019; Kalashnikova et al., 2019). The research of the procedure of parameters identification for the technological innovations management model in economic systems is of particular importance (Babenko et al., 2019). The processes of production, exchange, distribution, and consumption of material benefits that are dynamic, require clear coordination and are directed at the forming of the single model are the basis of the socio-economic system of each country (Voynarenko \& Honchar, 2018). The model of regional development asymmetry analysis allows to detect of factors-sources of regional development misbalances and improve the feasibility and quality of managerial decisions regarding the forming of regional policy (Huryanova et al., 2012; Melnyk et al., 2018). The models of motivation at the enterprise based on the process of staff motivation to improve the efficiency of creativity management are developed and the method to activate innovative processes that stipulates the development and justification of the model's main components is defined (Krykulenko, 2014; Vasyltsiv et al., 2017). In our opinion, the process of scientific research should be expanded by the construction of the model of economic system management efficiency in a region in the context of investment capacity development in order to secure the proper competitiveness level of a certain region and a country in general.

\section{Materials and method}

From the viewpoint of classical approaches to the management of socio-economic systems, the efficiency of the management system is determined by three major focus areas:

1) Economic efficiency defines the ratio of results and expenses and emerges when the ratio exceeds 1 :

$$
\mathrm{E}=\frac{\mathrm{R}}{E_{x p}}>1,
$$

where, $E, R$ and $E_{x p}$ are economic efficiency, results (profit, added value, goods, etc.) and expenses (financial, material, temporal, etc.), respectively.

2) The productivity of the system's functioning represents the level of the use of available resources from the viewpoint of their impact on the production of goods or services. Ukrainian enterprises have completely ignored the productivity problem at all management levels in conditions of transformation. The productivity rate has not been introduced in the practice of statistical recording. So, the comparison of productivity levels among enterprises is a complicated process. Lack of respective information base prevents the tracking of productivity dynamics at domestic enterprises. However, under current conditions, the search for the reserves to improve the enterprises' productivity, i.e. the opportunities the enterprises have not been used due to various reasons, should become their primary task (Brodska, 2012). According to the International Labor Organization, productivity is the efficiency of the use of resources - labor, capital, land, materials, energy, and information in the production of various goods and provision of services. At the level of regions, the productivity can be calculated as the ratio of the volumes of produced goods and services and the volumes of used resources (labor, material resources, investment).

$$
P_{N}=\frac{Q_{G}}{Q_{N}} \rightarrow \max ,
$$


where, $P_{N}$ represents the productivity of resource $n$ (production factor), $Q_{G}$ denotes volumes of produced goods (services) in the defined period and $Q_{N}$ is the volumes (quantity) of used resources or production factors in the defined period, respectively.

3) The performance of an economic system's functioning indirectly mirrors the efficiency of strategic and tactical decisions made at all levels of the regional administration. According to Trut (2014), “... performance - is the level of achievement of planned results (planned tasks, goals). The nature of "results" in relation to functioning and development of an organization is very deep and multifaceted because modern organizations have various objectives". Therefore, the performance shows the level of achievement of the region's development goals for a certain period and represents the efficiency and quality of regional authorities' activity. In general terms, the performance is calculated as the ratio of actual and planned rates:

$$
P=\frac{P_{a}}{P_{t}} \geq 1,
$$

where $P, P_{a}$ and $P_{t}$ are performance of economic system's management in a region, actual rate of realization of certain activity type and target rate, respectively. The use of these formulas will contribute to the complex evaluation of the economic system management efficiency in the regions and comparative, dynamic, and structural analysis of economic activity at the regional level. Interpretation of received data and its use in substantiation of regional socio-economic development strategies and improvement of their implementation administration are important factors for evaluation of the economic system management efficiency in the regions. Therefore, in our opinion, the development of methodological grounds of evaluation of the economic system management efficiency in the regions based on economic efficiency, productivity, and performance rates is an urgent issue. It is also worth mentioning that the achievement of both economic and social development effects is an important part of the mission of a region's socio-economic development. Therefore, it is reasonable to supplement the calculation system with the social efficiency rate at the regional level. According to the goals of the research, the economic system management efficiency in a region can be defined as an integrated comparative evaluation of the results of the region's economic activity that determines the balance of economic and social efficiency, productivity of the use of resources capacity, and performance of the region's management for a certain period. Therefore, the suggested methodical approach to evaluation of the economic system management efficiency in a region stipulates the following stages (Fig. 1).

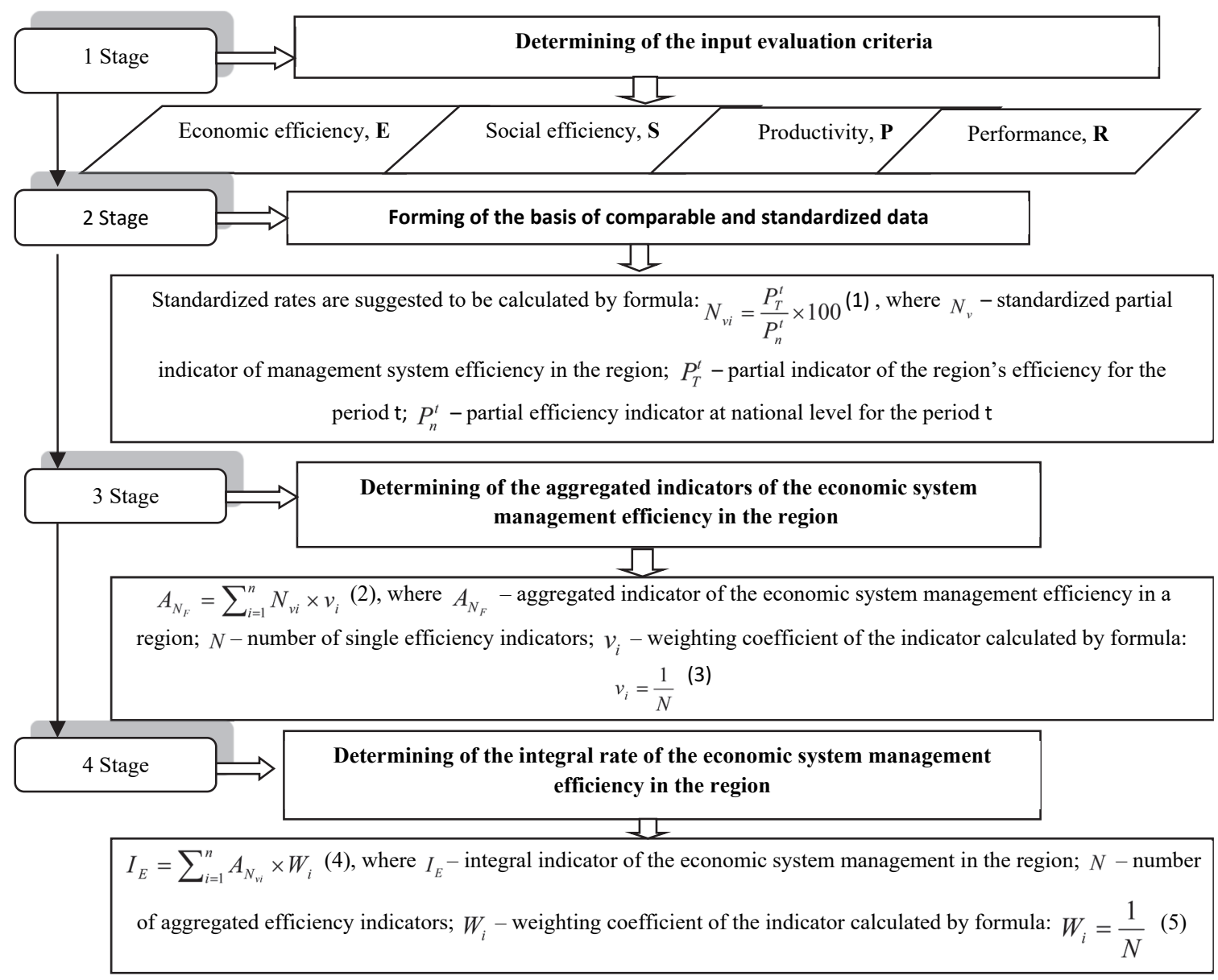

Fig. 1. Stages of evaluation of the economic system management efficiency in the region Source: developed by authors 
At the first stage, the main criteria and indicators of evaluation of the economic system management efficiency in the region should be determined. The conducted research proves that economic and social efficiency, the productivity of the use of resources capacity in the region and the performance of managerial actions are the most generalized criteria. Based on the aim of the research and access to statistical data on efficiency evaluation across Ukrainian regions, the system of single evaluation indicators represented in Table 1 is suggested.

Table 1

Criteria and indicators of evaluation of the economic system management efficiency in the region

\begin{tabular}{|c|c|c|c|}
\hline Criteria & Indicators & Calculation formula & Notation \\
\hline \multirow{3}{*}{ 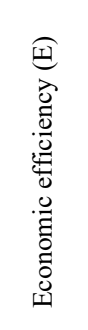 } & $\begin{array}{l}\text { Overall profitability of } \\
\text { economic entities }\end{array}$ & $e_{1}=\frac{P}{E_{x p}} \times 100$ & $\begin{array}{l}P-\text { gross profit of enterprises in the region, thous. UAH; } \\
E_{x p}-\text { gross expenditures of enterprises in the region, thous. UAH }\end{array}$ \\
\hline & Return on investment & $e_{2}=\frac{C I}{P} \times 100$ & $\begin{array}{l}C I \text { - capital investment in the development of the region, thous. } \\
\text { UAH }\end{array}$ \\
\hline & Economic activity profitability & $e_{2}=\frac{P}{Q}$ & $Q$ - volumes of sales of goods and services in the region \\
\hline$\sqrt{2}$ & Unemployment & $S_{1}=\frac{U}{E A P} \times 100$ & $\begin{array}{l}U-\text { unemployment rate, thous. persons; } \\
E A P \text { - economically active population, thous. persons }\end{array}$ \\
\hline
\end{tabular}

$\begin{array}{lcl}\text { Average wages } & S_{2} & S_{2} \text { - Statistical rate } \\ \begin{array}{l}\text { Capital investment per } \\ \text { employee }\end{array} & S_{3}=\frac{C I}{N E} & N E-\text { number of employees, thous. persons }\end{array}$

\begin{tabular}{|c|c|c|}
\hline Labor productivity in the region & $p_{1}=\frac{Q}{N E} \times 100$ & $Q$ - volumes of sales of goods and services in the region \\
\hline $\begin{array}{l}\text { Productivity of the use of } \\
\text { capital assets }\end{array}$ & $p_{2}=\frac{G R P}{C A}$ & $\begin{array}{l}G R P \text { - Gross Regional Product per capita, } \\
C A \text { - purchase value of capital assets, thous. UAH }\end{array}$ \\
\hline Energy use productivity & $p_{3}=\frac{G R P}{E}$ & $E$ - energy consumption in the region, tons of oil equivalent \\
\hline $\begin{array}{l}\text { Execution of the plan on } \\
\text { economic growth }\end{array}$ & $r_{1}=\frac{G R P_{a}}{G R P_{p}}$ & $\begin{array}{l}G R P_{a} \text { - actual Gross Regional Product per capita, thous. UAH; } \\
G R P_{p} \text { - planned Gross Regional Product per capita, UAH }\end{array}$ \\
\hline $\begin{array}{l}\text { Execution of the plan on } \\
\text { increase of disposable income } \\
\text { per capita, UAH }\end{array}$ & $r_{2}=\frac{D I_{a}}{D I_{p}}$ & $\begin{array}{l}D I_{a}-\text { actual disposable income per capita, } \mathrm{UAH} \\
D I_{p}-\text { planned income per capita in the region, } \mathrm{UAH}\end{array}$ \\
\hline $\begin{array}{l}\text { Execution of the plan on } \\
\text { foreign direct investment } \\
\text { attraction per capita in the } \\
\text { region, USD }\end{array}$ & $r_{3}=\frac{F I_{a}}{F I_{p}}$ & $\begin{array}{l}F I_{a}-\text { actual foreign direct investment per capita in the region, USD; } \\
F I_{p}-\text { planned foreign direct investment per capita in the region, } \\
\text { USD }\end{array}$ \\
\hline
\end{tabular}

Source: developed by authors

It is worth mentioning that according to suggested methodical recommendations, the list and number of indicators can be adapted depending on the goals of the research and supplemented by qualitative evaluation parameters. The use of the suggested system of indicators will contribute to a comprehensive analysis of the economic system management efficiency in the region under transformation and to determining strengths and bottlenecks (the region's profile) in the management of regional systems compared to average rates in Ukraine.

\section{Results and discussion}

In order to evaluate the efficiency, the indicators provided in the Table are calculated based on statistical records across oblasts of the Black Sea region of Ukraine. The results of calculation are given in the Table 2. 
Table 2

Indices of economic system management efficiency across oblasts of the Black Sea region of Ukraine

\begin{tabular}{|c|c|c|c|c|c|}
\hline Indicators & Period & Ukraine & Mykolayivska oblast & Odeska oblast & Hersonska oblast \\
\hline \multicolumn{6}{|c|}{ Economic efficiency (E) } \\
\hline \multirow{3}{*}{$\begin{array}{l}\text { Overall profitability of economic entities, } \% \\
\text { Growth, } \%\end{array}$} & 2015 & 1 & 9.8 & -2 & 12 \\
\hline & 2017 & 8.8 & 10.6 & 9 & 11.3 \\
\hline & & 7.8 & 0.8 & 11 & -0.7 \\
\hline \multirow{2}{*}{ Return on investment, $\%$} & 2015 & 174 & 134 & 163 & 201 \\
\hline & 2017 & 150 & 73 & 89 & 77 \\
\hline Growth, \% & & -24 & -61 & -74 & -124 \\
\hline \multirow{3}{*}{$\begin{array}{l}\text { Profitability, thous. UAH } \\
\text { Growth, \% }\end{array}$} & 2015 & 0.08 & 0.08 & 0.07 & 0.12 \\
\hline & 2017 & 0.08 & 0.06 & 0.05 & 0.07 \\
\hline & & -4.2 & -26.3 & -20.7 & -36.7 \\
\hline \multicolumn{6}{|c|}{ Social efficiency (S) } \\
\hline \multirow{3}{*}{$\begin{array}{l}\text { Unemployment, } \% \\
\text { Growth, \% }\end{array}$} & 2015 & 9.1 & 8.9 & 6.5 & 10.2 \\
\hline & 2017 & 9.5 & 10.3 & 7.3 & 11.1 \\
\hline & & 0.4 & 1.4 & 0.8 & 0.9 \\
\hline \multirow{2}{*}{ Average wages, UAH } & 2015 & 5230 & 5227 & 5154 & 4155 \\
\hline & 2017 & 8777 & 7879 & 8297 & 7206 \\
\hline Growth, \% & & 67.8 & 50.7 & 61.0 & 73.4 \\
\hline \multirow{2}{*}{ Capital investment per employee, thous. UAH } & 2015 & 32,8 & 33,0 & 22.1 & 22.0 \\
\hline & 2017 & 54.2 & 61.0 & 51.9 & 52.1 \\
\hline \multirow[t]{2}{*}{ Growth, $\%$} & & 65.4 & 84.9 & 134.9 & 136.6 \\
\hline & & Productivi & & & \\
\hline \multirow{2}{*}{ Labour productivity, thous. UAH } & 2015 & 686.1 & 584.8 & 523.6 & 381.4 \\
\hline & 2017 & 1023.7 & 801.3 & 849.8 & 546.0 \\
\hline \multirow{4}{*}{$\begin{array}{l}\text { Growth, \% } \\
\text { Energy use productivity, thous. UAH/ tons of } \\
\text { oil equivalent } \\
\text { Growth, \% }\end{array}$} & & 49.2 & 37.0 & 62.3 & 43.1 \\
\hline & 2015 & 0.05 & 0.03 & 0.05 & 0.04 \\
\hline & 2017 & 0.08 & 0.05 & 0.08 & 0.07 \\
\hline & & 65.02 & 48.19 & 63.85 & 59.28 \\
\hline \multirow{2}{*}{$\begin{array}{l}\text { Productivity of the use of capital assets, mln. } \\
\text { UAH }\end{array}$} & 2015 & 0.26 & 0.13 & 0.21 & 0.14 \\
\hline & 2017 & 0.39 & 0.18 & 0.31 & 0.24 \\
\hline \multirow[t]{2}{*}{ Growth, \% } & & 48.3 & 39.4 & 45.7 & 69.4 \\
\hline & & Performan & & & \\
\hline \multirow{3}{*}{$\begin{array}{l}\text { Execution of the plan on economic growth,\% } \\
\text { Growth, \% }\end{array}$} & 2015 & 95 & 98 & 96 & 93 \\
\hline & 2017 & 101 & 103.1 & 102.3 & 99.2 \\
\hline & & 6 & 5 & 6 & 6 \\
\hline \multirow{3}{*}{$\begin{array}{l}\text { Execution of the plan on increase of the income } \\
\text { of the population,\% } \\
\text { Growth, \% }\end{array}$} & 2015 & 103 & 101.5 & 102 & 104 \\
\hline & 2017 & 123 & 123 & 146 & 140 \\
\hline & & 20 & 22 & 44 & 36 \\
\hline \multirow{3}{*}{$\begin{array}{l}\text { Execution of the plan on foreign direct } \\
\text { investment attraction } \\
\text { Growth, \% }\end{array}$} & 2015 & 79 & 78 & 73 & 77 \\
\hline & 2017 & 65 & 58 & 71 & 67 \\
\hline & & -14 & -20 & -2 & -10 \\
\hline
\end{tabular}

Source: calculated by authors based on the data (Kherson regional administration, 2018; Ministry of Regional Development, Construction and Housing of Ukraine, 2017; Mykolayiv regional administration, 2018; Odessa regional administration, 2018; State Statistical Service of Ukraine, 2019)

The results of the conducted research show that the 2015-2017 dynamics is characterized by trends peculiar to Ukraine in general and the Black Sea region in particular:

1) The declining return on investment and profitability of the enterprises' operating activity, moreover, these indicators fall in the oblasts of the Black Sea region faster than in Ukraine. Hersonska oblast has the worst rates. In 2017, the profitability declined here by $124 \%$ compared to Ukraine (-24\%). Low volumes of production profitability caused by the significant growth of production costs, namely the energy expenses, amount to averagely $0.06 \mathrm{UAH}$ of profit per $100 \mathrm{UAH}$ of produced goods. In 2017, they decreased by $26 \%$ compared to 2015 .

2) Despite declining profitability, the growing productivity of the use of capital assets is the positive trend, namely the labor productivity (from $37 \%$ in Mykolayivska oblast to $62 \%$ in Odeska oblast) and productivity of the use of energy resources in percent to GDP (from $48 \%$ in Mykolayivska oblast to $63 \%$ in Odeska oblast). This testifies to the gradual introduction of the resource-saving technologies and improvement of energy efficiency at enterprises and capital assets at their initial value.

3) Improving rates of social efficiency in economic activity are the positive trend that shows the insignificant but gradual raising of social standards in the region. Thus, in 2015-2017, the increase of average wages both in Ukraine and in the Black Sea region (on the average by $65 \%$ ) and the increase of capital investment per an employee that boosted the labor productivity in the period were quite significant and exceeded the planned rates for the period. However, improving social standards are accompanied by growing unemployment in the region, which provides for the conclusion about the impact of price factors on the development of these processes. 
4) While analyzing the performance of state and regional authorities in the context of the execution of target indicators, it is worth mentioning that in 2017 and 2017, the plans were overachieved in terms of growing disposable income on average by 3$4 \%$ and in terms of economic growth. In particular, in 2017, the GRP increase in the Black Sea region (except for Hersonska oblast) exceeded the planned one early in the year over 2-3\%. However, the execution of plans on increasing foreign investment per capita has a negative trend, and in $2015-2017$, it was $58-79 \%$ depending on the region and decreasing in dynamics. This testifies to the availability of significant problems related to the investment climate condition in Ukraine.

Preliminary analysis of the indices of the economic system management efficiency has detected the major problem issues that require greater attention of local authorities to the development of strategic and tactical solutions on the region's development in perspective, namely growing unemployment, declining enterprises' profitability and poor condition of the investment climate. The problems are common for all Ukrainian regions at the current transformation stage. Meanwhile, they are differently expressed across the regions and require efficient strategic decisions to overcome them based on general organizationaleconomic tools and regional mechanisms of influence.

The indicators characterize the weighted average estimations of the indices of management efficiency across main indicators groups: economic efficiency, social efficiency, productivity of the economic system, and performance of authorities on condition that within the target groups all the indicators are of equal weight in the evaluation system. Based on the data in the Table, the integral indices were calculated, and integrated parameters of the economic system management efficiency were generalized for 2015-2017 (Table 3).

Table 3

Calculation of the integral index of the economic system management efficiency in the Black Sea region of Ukraine

\begin{tabular}{lcccc}
\hline Indicators & Period & Mykolayivska oblast & Odeska oblast & Hersonska oblast \\
\hline Economic efficiency of the system's & 2015 & 32.3 & 23.6 & 37.0 \\
functioning (E) & 2017 & 62.9 & 56.4 & 72.8 \\
Social efficiency of the system (S) & 2015 & 102.5 & 88.2 & 97.4 \\
& 2017 & 94.3 & 79.9 & 66.7 \\
System's productivity (P) & 2015 & 66.9 & 83.9 & 64.2 \\
System's performance (R) & 2017 & 61.8 & 86.1 & 65.7 \\
& 2015 & 99.1 & 108.6 & 104.0 \\
Calculation & 2017 & 96.1 & & \\
Integral index of the economic system & 2015 & \multicolumn{2}{c}{$I=E^{0.25}+S^{0.25}+P^{0.25}+R^{0.25}$} & 74.1 \\
management efficiency (I) & 2017 & 75.2 & 83.0 & 77.3 \\
\hline
\end{tabular}

Source: calculated by authors

The results of calculations show that the efficiency of economic system management in all oblasts of the Black Sea region of Ukraine is on about the same level, which is $20 \%$ less compared to the reference value for Ukraine. Declining overall management efficiency in 2017 compared to 2015 in Mykolayivska and Hersonska oblasts by 3.6 and 3.3\% is the negative aspect. Odeska oblast shows some slight growth (9.8\%). However, there are certain problems in each oblast, and their solution will raise management efficiency in the region.

\section{Conclusion}

The conducted research substantiates the authors' approach to determine the economic system management efficiency in the region, which provides that it is the result of the complex integrated comparison of the outcome economic activity indicators that defines the balance of economic and social efficiency, productivity of the use of resources capacity and performance of the region's management for a certain period. The respective evaluation criteria are systematized: economic, social efficiency of economic activity in the region, productivity of the use of resources and performance of the management system. The system of evaluation indicators by each criterion and mathematical apparatus to calculate them is suggested.

The authors have presented the developed methodical approaches to evaluate the economic system management efficiency in the region under transformation that helps determine the current level against similar indicators achieved within the country and the tendencies influenced by regional factors, form the "economic system management profile", and identify of strengths and bottlenecks.

Following the authors' approach, the economic system management efficiency is evaluated across the oblasts of the Black Sea region of Ukraine. The conducted analysis revealed the fact that the economic system management efficiency is at about the same level in all oblasts of the Black Sea region, which is $20 \%$ lower than the reference value for Ukraine. Declining overall 
management efficiency in 2017 compared to 2015 in Mykolayivska and Hersonska oblasts by 3.6 and $3.3 \%$ is the negative aspect. Odeska oblast shows some slight growth (9.8\%). However, there are certain problems in each oblast, and their solution will raise management efficiency in the region.

\section{References}

Babenko, V., Nakisko, O., Latynin, M., Rudenko, S., Lomovskykh, L., \& Girzheva, O. (2019). Procedure of Identifying of the Parameters of the Model of Management of Technological Innovations in Economic Systems, 2019 IEEE International Scientific-Practical Conference Problems of Infocommunications, Science and Technology (PIC S\&T), Kyiv, Ukraine, 324328. https://doi.org/10.1109/PICST47496.2019.9061259

Barna, M., Popadynets, N., \& Shults, S. (2017). Differences in consumer buying behavior in consumer markets of the EU member states and Ukraine. Economic Annals-XXI, 166(1-2), 26-30. https://doi.org/10.21003/ea.V166-05

Brodska, D. V. (2012). Evaluation of a company's productivity as a component of the system of if its efficient functioning maintenance. Bulletin of Dnipropetrovsk university, 6(4), 111-117.

Huryanova, L. S., Klebanova, T. S., Serhiyenko, O. A., \& Honcharenko H. S. (2012). Model of region a development asymmetry analysis. Economic problems, 2, 27-33.

Kalashnikova, T., Koshkalda, I., \& Trehub, O. (2019). Mathematical methods of data processing in formation and evaluation of sectoral structure in agricultural enterprises Global Journal of Environmental Science Management, 5(SI), 87-95. http://dx.doi.org/10.22034/gjesm.2019.05.SI.10

Kasaeva, J. (2019). Developing the methodology of assessing the potential of countries to attract foreign direct investment. Marketing and Management of Innovations, 4, 292-307. http://doi.org/10.21272/mmi.2019.4-23

Khaustova, K. Stehnei, M., Irtyshcheva, I., \& Boiko, Y. (2017). Modeling of strategic control system in the context of sustainable development of enterprise. Problems and Perspectives in Management, 15(3), 212-223. http://dx.doi.org/10.21511/ppm.15(31).2017.05

Khaustova, K. Stehnei, M., Irtyshcheva, I., \& Boiko, Y. (2019). Strategic Priorities and Effectiveness of the Implementation of the State Policy for Sustainable Agricultural Development in Ukraine. Public Policy and Administration, 18(2), $194-208$. https://doi.org/10.13165/VPA-19-18-2-02

Kherson regional administration. (2018). Report on execution of 2017 Hersonska Oblast Socio-Economic Development. Plan Retrieved March, 09, 2020 from: http://khor.gov.ua/749-pro-zviti-shhodo-rezultativ-vikonannya-planu-zahodiv-zrealizatsiyi-u-2016-2017-rokah-strategiyi-rozvitku-hersonskoyi-oblasti-2020-rok

Kolomiyets, I., \& Popadynets, N. (2016). Trade at Ukrainian internal market: the development mechanism. Actual problems of Economics, 1(175), 69-75

Krykulenko, D. (2014). Development of the staff motivation model as a key component of innovative activity development. Marketing and Management of Innovations, 1, 183-191

Melnyk, M., Korcelli-Olejniczak, E., Chorna, N., \& Popadynets, N. (2018). Development of regional IT clusters in Ukraine: Institutional and investment dimensions. Economic Annals-XXI, 173(9-10), 19-25. https://doi.org/10.21003/ea.V173-03

Ministry of Regional Development, Construction and Housing of Ukraine. (2017). Monitoring of the regions' socio-economic development in 2017. Retrieved March, 02, 2020 from: http://www.minregion.gov.ua/wpcontent/uploads/2018/05/Reytingova-otsinka-za-2017-rik-prezentatsiyni-materiali.pdf

Mykolayiv regional administration. (2018). Report on execution of 2017 Mykolayivska Oblast Socio-Economic Development Plan. Retrieved March, 09, 2020 from: http://www.mk.gov.ua/store/files/1519830960.pdf

Odessa regional administration. (2018). Report on execution of 2017 Odeska Oblast Socio-Economic and Cultural Development Program. Retrieved March, 09, 2020 from: https:/oda.odessa.gov.ua/statics/pages/files/5b028891cfb75.pdf

Panukhnyk, O., Popadynets, N., \& Fedotova Y. (2019). Analysis and modeling of factor determinants of food provision at consumer market of Ukraine. Global Journal of Environmental Science Management, 5(SI), $215-226$. http://dx.doi.org/10.22034/gjesm.2019.05.SI.24

Richardson, L. (1960). Arms and insecurity. Pittsburg : Boxwood.

Stroyko, T., Irtyshcheva, I., \& Stehney, M. (2013) Public regulation of integration systems development in agri-food sphere of Ukraine under globalization. Actual Problems of Economics, 3,125-134.

State Statistical Service of Ukraine. (2019). Regions of Ukraine - 2018. Retrieved March, 09, 2020 from: http://www.ukrstat.gov.ua

Stroyko, T., Irtyshcheva, I., \& Stehney, M. (2015) Factors and features of environmental sustainable rural development under global challenges Actual Problems of Economics, 1, 316-322

Weidlich, W. (1988). Stability and Cyclicity in Social Systems. BehavioralScience, 33, 241-256.

Trut, O. (2014). On management criteria and measurement indicators of an organization's performance. Trade, commerce, entrepreneurship, 17, 153-156

Vasyltsiv, T., Lupak, R., \& Osadchuk, Yu. (2017). Assessment of the level of penetration of import dependence in the context of the import substitution policy in Ukraine. Economic Annals-XXI, 167 (9-10), 13-17. 
Voynarenko, M, \& Honchar, O. (2018). Transformation of socio-economic systems under integration changes. European Economy Journal, 17(2), 225-243

Yakubiv, V. M. (2015). Accounting and analytical methods of diagnostics improvement for enterprises' organizational development. Economic Annals-XXI, 3-4(1), 68-71.

Yakubiv V., Panukhnyk, O., Shults, S., Maksymiv, Y., Hryhoruk, I., Popadynets, N., Bilyk, R., Fedotova, Y., Bilyk, I. (2020) Application of Economic and Legal Instruments at the Stage of Transition to Bioeconomy. AHFE 2019. Advances in Intelligent Systems and Computing, vol 9656 656-666. https://doi.org/10.1007/978-3-030-20454-9_64

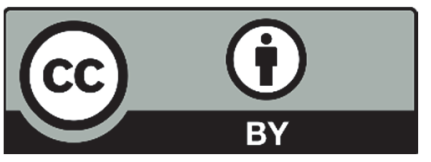

(C) 2020 by the authors; licensee Growing Science, Canada. This is an open access article distributed under the terms and conditions of the Creative Commons Attribution (CC-BY) license (http://creativecommons.org/licenses/by/4.0/). 